\title{
STABILITY OF MANGO CUBES PRESERVED BY HURDLE TECHNOLOGY
}

\author{
Estabilidade de cubos de manga conservados pela tecnologia de obstáculos
}

\author{
Henriette Monteiro Cordeiro de Azeredo ${ }^{1}$, Fátima Beatriz Silva de Araújo ${ }^{2}$, Deborah dos Santos Garruti ${ }^{1}$, \\ Ana Amélia Martins Queiroz ${ }^{2}$, Gustavo Adolfo Saavedra Pinto ${ }^{3}$
}

\begin{abstract}
Fruit preservation by hurdle technology is based on combinations of low levels of various antimicrobial factors (hurdles) acting synergistically resulting in a shelf stable high moisture, fresh-like product. The objective of this work was to evaluate the stability of mango cubes obtained by combining the following hurdles: water activity reduction, $\mathrm{pH}$ reduction, and chemical preservation. Tommy Atkins mangoes, previously washed, sanitized and peeled, were cut into cubes of approximately 8 $\mathrm{cm}^{3}$. The cubes were osmotically dehydrated under stirring (150 rpm) at $46^{\circ} \mathrm{C}$ in a sucrose solution at $65.5^{\circ}$ Brix added with $2 \%$ citric acid and $0.2 \%$ potassium sorbate, during two hours. The product was drained, packed in low-density polyethylene bags and stored at room temperature (about $25^{\circ} \mathrm{C}$ ) during three months. The combination of hurdles on the final product (water activity, 0.96; pH, 3.99; potassium sorbate content, $396 \mathrm{mg} . \mathrm{kg}^{-1}$ ) was not effective to make it shelf stable, since the count of yeasts and molds increased. The cubes underwent $\mathrm{pH}$ reduction and color losses during storage. Furthermore, the acceptance of the product, as well as, the mango flavor intensity, decrease significantly with storage time.
\end{abstract}

Index terms: mango; hurdle technology; osmotic dehydration.

\section{RESUMO}

A conservação pela tecnologia de obstáculos baseia-se na combinação de vários fatores antimicrobianos (obstáculos), todos aplicados em baixos níveis, atuando sinergicamente e resultando em um produto de alta umidade, semelhante ao correspondente fresco, e com boa estabilidade à temperatura ambiente. Conduziu-se este trabalho com o objetivo de avaliar a estabilidade de cubos de manga conservados pela combinação dos seguintes obstáculos: redução da atividade de água, redução do pH e conservação química. Mangas Tommy Atkins, previamente lavadas, sanitizadas e descascadas, foram cortadas em cubos de aproximadamente $8 \mathrm{~cm}^{3}$. Os cubos foram desidratados osmoticamente, sob agitação (150 rpm), a $46^{\circ} \mathrm{C}$ em uma solução de sacarose a $65,5^{\circ}$ Brix contendo $2 \%$ de ácido cítrico e $0,2 \%$ de sorbato de potássio, durante duas horas. O produto foi drenado, acondicionado em sacos de polietileno de baixa densidade e estocado à temperatura ambiente (cerca de $25^{\circ} \mathrm{C}$ ) durante três meses. A combinação de obstáculos não foi suficiente para tornar o produto estável, já que a contagem de fungos filamentosos e leveduras aumentou. Os cubos sofreram redução de $\mathrm{pH}$ e perda de cor durante a estocagem. Além disso, a aceitação do produto, assim como a intensidade do sabor da manga, diminuiram significativamente com o tempo de estocagem.

Termos para indexação: manga, tecnologia de obstáculos, desidratação osmótica.

(Recebido para publicação em 4 de maio de 2004 e aprovado em 28 de março de 2005)

\section{INTRODUCTION}

Conventional fruit preservation methods are usually based on a single preservation factor, applied at such a high level that causes noticeable sensory changes on the fruit. The hurdle technology, or combined methods technology (CMT), on the other hand, is based on combining low levels of two or more preservation factors (hurdles). No single factor is responsible for making the product stable, but rather the stability results from the synergism among the combined factors. The hurdle technology produces minimal sensory changes, which makes the products more acceptable than those obtained by conventional methods (AGUILERA \& CHIRIFE, 1994). Since the water activity is only slightly reduced, the products obtained by hurdle technology are known as high moisture products. In the context of hurdle technology, the method generally used to reduce water activity of fruits is the osmotic dehydration, which consists in dipping the fruit in a hyperconcentrated solution. The resulting of osmotic pressure promotes water loss, reducing water activity of the fruit and favoring its stability.

The objective of this work was to evaluate the stability of high moisture mango (Mangifera indica L.) cubes produced by combining the following preservation factors: water activity reduction (by osmotic dehydration), $\mathrm{pH}$ reduction (by adding citric acid to the osmotic solution), and chemical preservation (potassium sorbate added to the osmotic solution).

1. Engenheiras de Alimentos Dras., Pesquisadoras III - Embrapa Agroindústria Tropical - Rua Dra. Sara Mesquita, 2270 - 60511-110 - Fortaleza, CE ette@cnpat.embrapa.br

2. Estudantes de iniciação científica - Embrapa Agroindústria Tropical.

3. Químico Dr.- Pesquisador III - Embrapa Agroindústria Tropical. 


\section{MATERIAL AND METHODS}

Tommy Atkins mangoes, purchased in the local market (Fortaleza, CE, Brazil), were washed, sanitized, peeled, cut into cubes of $8 \mathrm{~cm}^{3}$ and osmotically dehydrated in a sucrose solution at $65^{\circ}$ Brix with added $2 \%$ citric acid and $0.2 \%$ potassium sorbate. Dehydration was accomplished in an open kettle at $46^{\circ} \mathrm{C}$ under stirring (150 rpm) for 2 hours. The product was then drained in a sieve for 2 minutes. The dehydrated cubes were packaged in low-density polyethylene bags and stored at room temperature (about $25^{\circ} \mathrm{C}$ ) during three months.

At the beginning of the storage time, the product was characterized with regard to the potassium sorbate content (MAURO, 1992), water activity, pH, total titratable acidity, moisture and total soluble solid contents (AOAC, 1995). Additionally, sensory tests were carried out, named, a mango flavor intensity test, in a 7-point structured scale (1 - "very weak" to 7 - "very strong, fresh mango-like"), and acceptance tests, in 9-point structured hedonic scales (MEILGAARD et al., 1987).

Monthly during storage, the product was submitted to water activity, $\mathrm{pH}$, and color (Hunter) analyses, as well as, the same sensory tests as those performed at the zero time of the storage. The data was submitted to regression analyses as a function of storage time, and the means were compared by Tukey's multiple range tests. Determination of mesophilic aerobes and counts of yeasts and molds (according to AMERICAN PUBLIC HEALTH ASSOCIATION, as described by DOWNES \& ITO, 2001) were also carried out, to evaluate microbial stability of the product.

\section{RESULTS AND DISCUSSION}

The osmotically dehydrated mango cubes presented the following characteristics: water activity, 0.96; $\mathrm{pH}, 3.99$; total titratable acidity, $0.65 \%$ citric acid; moisture content, 59.80\%; soluble solid content, $36.4^{\circ}$ Brix; potassium sorbate content, $396 \mathrm{mg} . \mathrm{kg}^{-1}$.

Figure 1 presents the frequency histograms from the sensory data, showing distribution of sensory responses to the tests applied to high moisture mango cubes at the beginning of the storage time. Most of the hedonic responses were within the acceptance ranges (higher than 5): $80 \%$ for appearance; $67 \%$ for flavor; and $87 \%$ for texture. The hedonic scores with the highest frequencies (modes) were the following: 8 for appearance
(40\%); 7 for flavor (23\%); and 7 for texture (37\%). According to $63 \%$ of the panelists, the mango flavor intensity of the processed product was near the middle of a scale in which the maximum score was labeled as "very strong, fresh mango-like". So, it is reasonable to suppos e that the product may have lost some flavor during processing. Actually, the solution flowing out of the fruit during osmotic dehydration consists of water and some natural solutes such as organic acids and some flavor compounds (Shi \& Le Maguer, 2003).

Table 1 indicates that the acceptance of the product, as well as the mango flavor intensity, decreased significantly throughout the storage time. These changes may be partially attributed to microbial growth. In spite of the decreased acceptance, all the hedonic scores had remained in the lower half of the acceptance region (5-7 in the hedonic scale).

The results of the physico-chemical analyses of the product during storage are presented in Table 2. A significant $\mathrm{pH}$ reduction was probably due to microbial growth (Table 3). The product underwent orange color losses, since the color parameters a and $\mathrm{b}$ decreased with storage time. Actually, because of their high unsaturation degrees, carotenoids are highly susceptible to oxidation, which result in discoloration (RODRIGUEZ-AMAYA et al., 1984).

The counts of mesophilic aerobes were lower than 10 UFC. ${ }^{-1}$ during 3 months, but the determination of yeasts and molds increased from less than 100 UFC. ${ }^{-1}$ to values of about $10^{4}-10^{5}$ UFC.g ${ }^{-1}$ (Table 3). For this reason, the stability evaluation was interrupted at 3 months of storage, and the product was considered not stable. It may be attributed to a unsatisfactory combination of hurdles. Chanes et al. (1994) mentioned several stable fruit products obtained by similar combinations of hurdles, except by much higher sorbate concentrations. It is also important to know that the optimum functionality of the sorbate strongly depends on $\mathrm{pH}$. At $\mathrm{pH} 4.0$, about twice the sorbate concentration required at $\mathrm{pH} 3.0$ is needed to achieve the same antimicrobial effect (PADILLA-ZAKOUR, 1998). So, future works might involve either high levels of the hurdles used in this work (higher sorbate concentrations and/or lower $\mathrm{pH}$ ) or additional hurdles (e.g. edible coatings, storage under refrigeration), in order to obtain a product with higher microbiological (and possibly sensory) stability. 

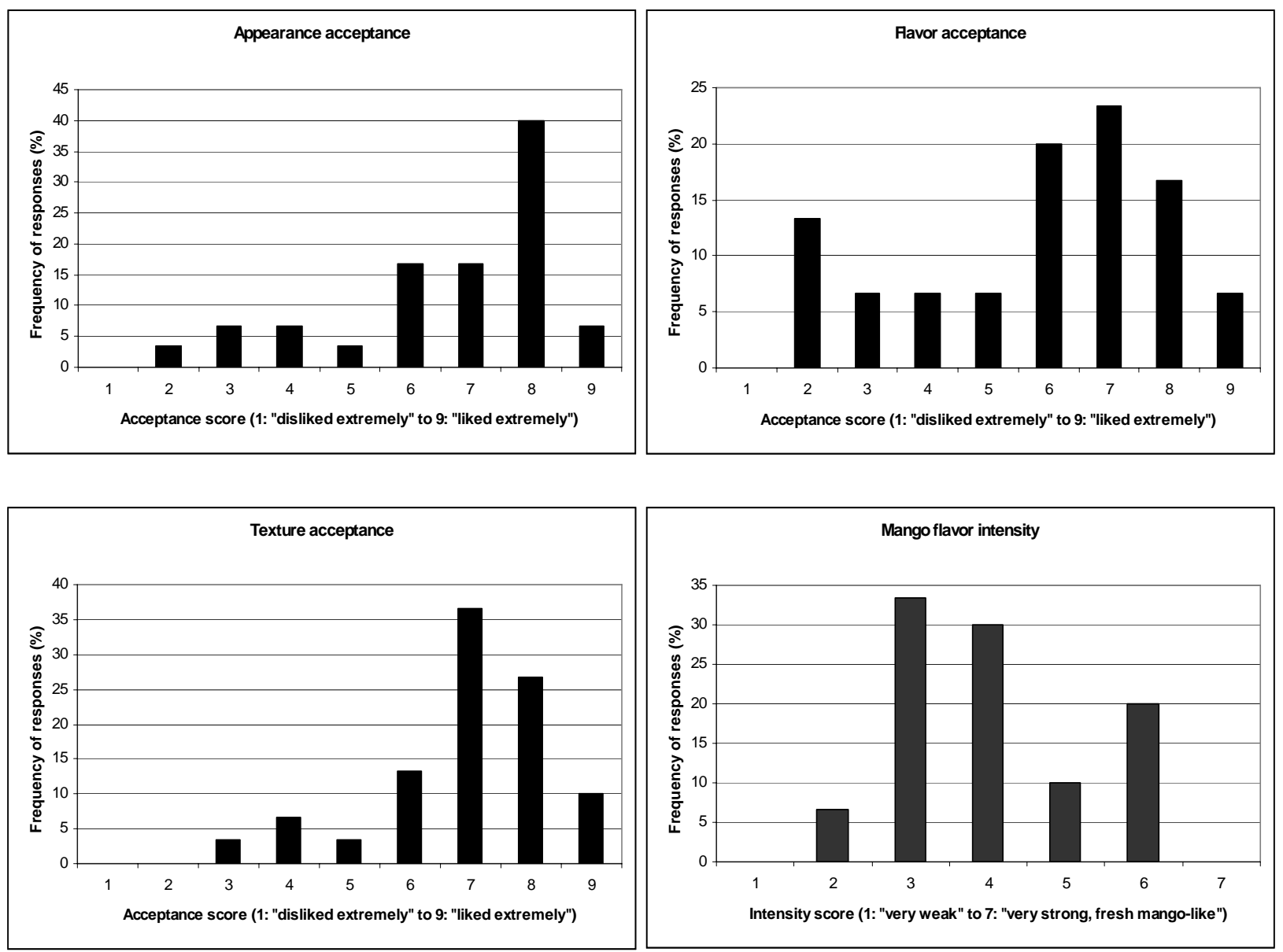

FIGURE 1 - Distribution of sensory responses from high moisture mango cubes at the beginning of the storage time.

TABLE 1 - F-test and Tukey's test results for the sensory attributes of high moisture mango cubes as a function of storage time.

Means of the attributes during

\begin{tabular}{lcccccc}
\multicolumn{1}{c}{ Attributes } & $\boldsymbol{F}$ & $\boldsymbol{p}$ & \multicolumn{4}{c}{ storage time (months) } \\
\cline { 4 - 7 } & & & $\mathbf{0}$ & $\mathbf{1}$ & $\mathbf{2}$ & $\mathbf{3}$ \\
\hline Appearance acceptance & 13.30 & $<0.01$ & $6.67 \mathrm{ab}$ & $6.77 \mathrm{a}$ & $5.97 \mathrm{c}$ & $6.30 \mathrm{bc}$ \\
Flavor acceptance & 15.50 & $<0.01$ & $5.83 \mathrm{a}$ & $5.17 \mathrm{~b}$ & $5.00 \mathrm{~b}$ & $5.33 \mathrm{~b}$ \\
Texture acceptance & 12.70 & $<0.01$ & $6.93 \mathrm{a}$ & $6.73 \mathrm{ab}$ & $6.17 \mathrm{c}$ & $6.43 \mathrm{bc}$ \\
Mango flavor intensity & 11.65 & $<0.01$ & $4.03 \mathrm{a}$ & $3.87 \mathrm{a}$ & $4.00 \mathrm{a}$ & $3.47 \mathrm{~b}$ \\
\hline
\end{tabular}

Bolded $\mathrm{F}$ values are significant $(\mathrm{p} \leq 0.05)$. Values in the same raw followed by the same letter are not significantly different $(\mathrm{p} \leq 0.05)$. 
TABLE 2 - F-test and Tukey's test results for the physico-chemical attributes of high moisture mango cubes as a function of storage time.

Means of the attributes during

\begin{tabular}{|c|c|c|c|c|c|c|}
\hline \multirow[t]{2}{*}{ Attributes } & \multirow[t]{2}{*}{$\boldsymbol{F}$} & \multirow[t]{2}{*}{$p$} & \multicolumn{4}{|c|}{ storage time (months) } \\
\hline & & & $\mathbf{0}$ & 1 & 2 & 3 \\
\hline Water activity & 1.03 & 0.33 & 0.965 a & 0.965 a & 0.966 a & $0.963 \mathrm{a}$ \\
\hline Moisture content (\%) & 1.85 & 0.26 & $59.80 \mathrm{a}$ & 61.23 a & 58.46 a & $60.68 \mathrm{a}$ \\
\hline Total titratable acidity (\% citric acid) & 4.06 & 0.04 & 0.65 a & $0.68 \mathrm{ab}$ & $0.72 \mathrm{~b}$ & $0.71 \mathrm{~b}$ \\
\hline $\mathrm{pH}$ & 15.33 & $<0.01$ & 3.99 a & $3.83 \mathrm{~b}$ & $3.79 \mathrm{~b}$ & $3.81 \mathrm{~b}$ \\
\hline Total soluble solids ( $\left.{ }^{\circ} \mathrm{Brix}\right)$ & 0.68 & 0.49 & $36.4 \mathrm{a}$ & 38.8 a & 35.9 a & $37.2 \mathrm{a}$ \\
\hline Potassium sorbate content $\left(\mathrm{mg} . / \mathrm{kg}^{-1}\right)$ & 0.25 & 0.61 & 396 a & 377 a & 386 a & 379 a \\
\hline \multirow{3}{*}{ Color } & 0.31 & 0.58 & $61.71 \mathrm{a}$ & 60.96 a & 59.93 a & $63.04 \mathrm{a}$ \\
\hline & 4.25 & 0.04 & $6.24 \mathrm{a}$ & $4.95 \mathrm{~b}$ & $4.22 \mathrm{c}$ & 3.92 c \\
\hline & 25.61 & $<0.01$ & $65.12 \mathrm{a}$ & $61.63 \mathrm{a}$ & $57.26 \mathrm{a}$ & $50.43 \mathrm{~b}$ \\
\hline
\end{tabular}

Bolded $\mathrm{F}$ values are significant ( $\mathrm{p} \leq 0.05$ ). Values in the same raw followed by the same letter are not significantly different ( $\mathrm{p} \leq 0.05)$.

TABLE 3 - Results of the microbiological analyses of high moisture mango cubes.

\begin{tabular}{|c|c|c|c|c|c|c|}
\hline Storage time (months) & $\begin{array}{c}\text { TC } \\
\left(\text { NMP. }^{-1}\right)\end{array}$ & $\begin{array}{c}\text { FC } \\
\left(\mathrm{NMP} \cdot \mathrm{g}^{-1}\right)\end{array}$ & $\begin{array}{c}\text { EC } \\
\left(\text { NMP. }^{-1}\right)\end{array}$ & $\begin{array}{c}\text { MA } \\
\left(\text { UFC. }^{-1}\right)\end{array}$ & $\begin{array}{c}\text { YM } \\
\left(\text { UFC. } \mathbf{g}^{-1}\right)\end{array}$ & $\begin{array}{l}\text { Salmonella } \\
\quad(25 \mathrm{~g})\end{array}$ \\
\hline 0 & $<3$ & $<3$ & $<3$ & $<10$ & $<100$ & absence \\
\hline 1 & $<3$ & $<3$ & $<3$ & $<10$ & $5.0 \times 10^{4}$ & absence \\
\hline 2 & $<3$ & $<3$ & $<3$ & $<10$ & $1.8 \times 10^{5}$ & absence \\
\hline 3 & $<3$ & $<3$ & $<3$ & $<10$ & $1.2 \times 10^{5}$ & absence \\
\hline
\end{tabular}

Each value was the average of a triplicate determination. TC $=$ total coliforms $(\mathrm{NMP} / \mathrm{g}) ; \mathrm{FC}=$ faecal coliforms $(\mathrm{NMP} / \mathrm{g}) ; \mathrm{EC}=$ E. coli $(\mathrm{NMP} / \mathrm{g}) ; \mathrm{MA}=$ determination of mesophilic aerobes $(\mathrm{UFC} / \mathrm{g}) ; \mathrm{YM}=$ count of yeasts and molds (UFC/g). 


\section{CONCLUSIONS}

The high moisture mango cubes presented significant $\mathrm{pH}$ reduction and orange color loss during storage, while the water activity remained stable.

Although the product acceptance has remained within the acceptance ranges during three months of storage, the acceptance decreased significantly throughout time. The mango flavor intensity was considered remarkably lower than that of fresh mangoes since the beginning of the storage, and decreased further during storage.

The combination of hurdles (water activity = 0.96; $\mathrm{pH}=3.97$; potassium sorbate concentration $=396$ $\mathrm{mg} \cdot \mathrm{kg}^{-1}$ ) was not effective to make the product microbiologically stable, since the counts of yeasts and molds increased with storage time.

\section{REFERENCES}

AGUILERA, J. M.; CHIRIFE, J. Combined methods for the preservation of foods in Latin America and CYTED-D project. Journal of Food Engeneering, London, v. 22, n. 1-4, p. 433-444, Apr. 1994.

ASSOCIATION OF OFFICIAL ANALITICAL CHEMISTS. Official methods of analysis of AOAC International. 16. ed. Arlington, 1995.

CHANES, J. W.; ALZAMORA, S. M.; RAPIA, M. S.; ARGAIZ, A. Aplicaciones de los factores combinados en frutas y hortalizas. In: Maupoey, P. F.; Grau, A. A.;
Boix, A. C. Aplicacion de factores combinados en la conservacion de alimentos. Valencia: Universidade Politecnica de Valencia, 1994. p. 155-166.

DOWNES, F. P.; ITO, H. Compendium of methods for the microbiological examination of foods. 4. ed. Washington: American Public Health Association, 2001. $600 \mathrm{p}$.

MAURO, M. A. Cinética da desidratação osmótica de banana nanica. 1992. 183 f. Mestrado (Dissertação) - Universidade Estadual de Campinas, Campinas, 1992.

MEILGAARD, M.; CIVILLE, G. V.; CARR, B. T. Sensory evaluation techniques. Boca Raton: CRC, 1987. v. 1, 125 p.

PADILLA-ZAKOUR, O. Chemical food preservatives: benzoate and sorbate. Venture, Geneva, v. 1, n. 2, $1998 . \quad$ Available at: $<$ http://www.nysaes.cornell.edu/fst/fvc/Venture/venture 2_chemical.html >. Access in: 10 july 2004.

RODRIGUEZ-AMAYA, D. B.; BOBBIO, F. O.; BOBBIO, P. A. Curso sobre pigmentos naturais. Campinas: Sociedade Brasileira de Ciência e Tecnologia de Alimentos, 1984. 56 p.

SHI, J.; LE MAGUER, M. Mass transfer in cellular material at solid-liquid contacting interface. LebensmittelWissenschaft und-Technologie, London, v. 36, n. 1, p. 3-11, Feb. 2003. 